C. I. F., XIX-XX (1993-1994) 77-87

\title{
MELVILLE'S CHILDHOOD EXPERIENCES AND THEIR INFLUENCE ON HIS PERSONALITY AND WRITINGS*
}

\begin{abstract}
Julieta Ojeda Alba**
Universidad de La Rioja

RESUMEN. En este artículo sostenemos la hipótesis de la homosexualidad latente en el autor americano Herman Melville. Intentamos explicar esta propensión a través de un análisis de sus circunstancias y experiencias infantiles que parecen haberla favorecido. Se ilustra esto llamando la atención a aspectos como la peculiar relación que mantuvo con su madre. Es imposible determinar hasta qué punto Melville era consciente de sus idiosincrasias, pero sí podemos asegurar que su literatura refleja su característico enfoque del sexo. La génesis de personalidades como la de Claggart y de obras como MobyDick está sin duda en las inclinaciones sexuales de su creador.

ABSTRACT. In this article we attempt to support the theory that there was a latent homosexuality in the 19th century American author Herman Melville. We also seek to explain his penchant through an analysis of his childhood experiences and his family conditions, which seem to have fostered his personal attitudes towards men and women. An example of this is the peculiar relationship that he maintained with his mother. It is impossible to determine how aware he was of his natural inclinations, but we can say that his literature echoes his personal attitudes. Personalities as that of Claggart and books as Moby-Dick would have been unrealizable by a man who did not look at men the way he did.
\end{abstract}

In spite of the currently apparent freedom of speech when discussing certain subjects that have for so long been taboo in Western Society, one cannot help feeling somewhat uneasy in presenting certain arguments. The appropriateness of digging into an author's private life trying to discover some hidden fact or some overlooked circumstance that may have influenced the author's work is still a valid issue for some critics. Male friendship and the connotations of homosexuality that it may imply is one of these subjects. It is nevertheless this sensitive matter that will be discussed here

* Presentado el 8 de noviembre de 1993.

** Doctora en Filología Inglesa y Profesora de Inglés en el Departamento de Filologías Modernas de la Universidad de La Rioja. 
in relation to Herman Melville for it is observed that there are conditions in his life which favoured a potential homosexuality which accordingly influenced his work.

About the uneasiness that haunts the commentator when dealing with these subjects, it should be pointed out that if we hesitate about our right to meddle with such an intimate subject perhaps we should just as well question this right when examining all other circumstances in an author's life. At what point does inquiry invade privacy? Are subjects such as marital bliss, politics or depression fair but homosexuality unfair? Do we have the right to state, as it has been widely asserted, that Melville was for a time on the verge of a nervous breakdown or that his father died insane? If so, why should we balk when talking about the possibility of Melville being more interested in society with men than with women?

It is as crucial to understand Melville's sexual inclinations as it is to learn about his political beliefs. Both had an influence on the products of his imagination. They shaped his work in the way we now see it, and it is extremely doubtful that, had Melville not been a democrat or had he not had this way of looking at other men, he would have ever created characters like Claggart or Harry Bolton. The fact is that when a human being feels something deeply such as the need of a relationship with a male friend, the result may be the creation of a tragic situation of sexual repression like the one we are presented with in Billy Budd. It is in this light that we may understand his work more in the way he would have wanted us to.

Is there anything in Melville's childhood that might help us to understand and interpret the nature of his inclinations? Young Herman spent the first ten years of his life in a comfortable upper middle class atmosphere. Although his father was not doing very well in his business the family moved from one house to another and it seems to have always been to a better one. Thus the young ones of the family might have been unaware of any financial difficulties. Herman seems to have been as deeply loved by his parents as any other of his siblings. Allan, his father, refers to him in his letters with frequent terms of endearment such as "My beloved son Herman", etc. ${ }^{1}$ But if he was well loved he was not as well appreciated. There is evidence that both Melville's parents had made an early decision that Herman was inadequate. His mother wrote in 1824 when Herman was only five: "Herman does not appear so fond of his books as to injure his health". ${ }^{2}$ This apparent lack of appreciation prompts readers to infer that Herman's frustrations and idiosyncrasies started somewhere around this period.

He was moreover seen as inferior to his older brother Gansevoort who is referred to by their father as "a most promising child", ${ }^{3}$ while the younger Herman was described as being "backward in speech and somewhat slow in comprehension".

1. Jay Leyda, The Melville Log Vol. I. New York: Hartcourt, Brace and company, 1951, p. 25.

2. Leyda, p. 20.

3. Leyda, p. 6.

4. Leyda, p. 25. 
When Herman finally deserved their praise by winning a "best speaker" prize in High School they did not change their minds. They obviously did not understand what this achievement must have meant for the "backward child". Allan wrote to his brother-inlaw Peter introducing the news of Herman's accomplishment by saying: "You will be as much surprised as myself to know that Herman proved the best speaker... He has made rapid progress during the two last quarters", 5 and without wasting any more time on Herman's accomplishments he went on to enumerate Gansevoort's achievements. If Allan did not have any scruples about describing both his sons in these somewhat different written terms, he must have much more easily shown his bias in everyday life. The attitude of Melville's father seems to have been well known by the family, and Allan himself was aware of it. In a letter to the Gansevoorts he informed them that both Gansevoort and Herman would return to New York together, "without any feelings of jealousy or ideas of favoritism." 6 The need for such an explanation speaks for itself.

This favouritism of Melville's parents and their lack of appreciation of their second son's intellectual powers were not the only handicaps Herman had to face in his childhood. The well known fact that both Allan and Gansevoort were considered very good looking, while Herman was not, must have had an effect on Melville's selfconfidence. Moreover, would not it be natural that a child in these circumstances would attribute his problems to this lack of physical charm? It must indeed have been at a very early age when Herman first started appreciating male physical beauty and perhaps longing to possess it himself.

Isolation from peers was yet another handicap Herman had to face in his childhood. The Melville children were not allowed to play freely in the streets, as most children usually do. Allan reported to his mother-in-law in a letter informing her about the children: "My little companions behave remarkably well, and pass their whole time in the house, or at school... I do not allow them to run abroad or play in the street" 7 . This limitation of contact with peers no doubt had its effect on Herman who, as most children, might have begun yearning even more for those relationships of which he was deprived.

At this point we have a young boy who had long been underappreciated and who had been treated as inferior to his older brother; a boy who had not been allowed to have playmates outside the house and, most importantly, whose father and male model had suddenly died. Is it a wonder that the result is isolation and yearning for male relationship to replace his lost father and his missing playmates?

Melville kept these feelings of loneliness, inadequacy, and yearning for a friend all through his life. This is undoubtedly why the traits of the orphan, the outcast, and the Apollo coexist in different proportions in many of his characters. He represented

\footnotetext{
5. Leyda, p. 32.

6. Leyda, p. 27.

7. Leyda, p. 28.
} 
these characteristics in his very first published work on May 4 and 18, 1839 , "Fragments from a Writing-Desk", and he never completely abandoned them throughout his literary career which he ended with these same themes in Billy Budd. In the "Fragments" he depicts the relationship between a young man, L.A.V., who is presented without a family, and an older father figure, a wealthy educated man of noble features who is named as M. The young L.A.V. is thought by most critics to incarnate Herman himself.

At the same time we find in this early work the other theme that was going to be a constant in Melville's writings. L.A.V. is not only an orphan who engages in a friendship with another male, he is also a beautiful Apollo who describes himself as having limbs, "modelled in the symmetry of the Phidian Jupiter" and "belted round with self-esteem as with a girdle". ${ }^{8}$ Beauty and self-esteem were two qualities that Herman had felt long deprived of in comparison with his older brother and now, when he was going to publish something for the first time, he could possess them at least in his writings. This was a rather logical reaction. Melville could and did endow himself through literature with the accomplishments that life itself had denied him and for which he had yearned during his childhood and adolescence.

Was it only the feelings of being deprived of beauty that made him so extremely aware of this quality in males? Perhaps so, but it seems there was something else innate in him that made him appreciate his own sex more than the opposite. We cannot be sure, but what cannot be denied is that his evidenced keen appreciation and portrayal of male beauty reveals a somewhat homosexual vision of the world.

Appreciation of male beauty is in different degrees a constant in Melville's works and life. Among other examples we can mention his first novel Typee, where Melville says that Marnoo's cheeks and figure "might have entitled him to the distinction of standing for the statue of the Polynesian Apollo"9, Harry Bolton in Redburn who is described as "one of those small, but perfectly formed beings", 10 and Carlo, also in Redburn, whose "naked leg was as beautiful to behold as any lady's arm".11 This attention to male beauty culminates in Billy Budd where, in fact, the beauty of Billy is the catalyst of the action in the novel. Melville's interest in male beauty was not limited to just his works. He extended it to other areas of his life. In his journals he describes on February 26, 1857 the statue of Antinous, the young lover of emperor Hadrian, "Antinous, beautiful... head like mosse-rosse with curls and buds." 12 We

8. Herman Melville, "Fragments from a Writing Desk" Billy Budd and other Prose Pieces, Vol. 13, p. 383.

It is also possible that Melville is being ironic about his lack of beauty.

9. Herman Melville, Typee, p. 162.

10. Melville, Redburn, p. 278.

11. Melville, Redburn, p. 319.

12. Melville, Journal of a Visit to Europe and the Levant, p. 195. 
might question here his motivation in buying and keeping for so long in his parlour a copy of this particular statue.

It is important to note that these same feminine curls described in the statue of Antinous often formed part of the descriptions of Melville's male characters and it is likewise significant that in many instances Melville's handsome males had feminine or hermaphroditic characteristics. Even when writing about the strength of a whale's tail in chapter 86 of Moby-Dick, he manages to incorporate a description of Jesus' Italian images which have the same traits, "the soft, curled, hermaphroditical Italian pictures", to which he attributes "nothing of any power, but the mere negative feminine one of submission and endurance". ${ }^{13}$

Another crucial feature frequent in the world of Melville's imagination is the portrayal of friendship between two males. These relationships are usually ambiguous and much more complicated and extensive than we can even attempt to discuss in these few pages. I would like, nevertheless, to draw attention here to the fact that in such relationships one of the subjects has always been thought by the critics to represent Melville or what he would have liked to be. Examples of these relationships include the ones between main character and Jack Chase in White-Jacket, Harry Bolton and Redburn in Redburn and Queequeg and Ishmael in Moby-Dick. The subjects of these friendships possess in different measure the previously mentioned features. They are beautiful or handsome, they have no known origins and they are solitary and in search of a friend who sometimes has fatherly features. About the social and democratic significance of Melville's use of male friendship Robert K. Martin gives an interesting and coherent interpretation that also implies homosexuality. ${ }^{14}$

Apart from those literary friendships that may tell us of some obscure and unsatisfied needs, there was in his life a friendship that no doubt influenced his subsequent treatment of male relationships in literature, the one he had with Nathaniel Hawthorne. On August 5, 1850 an important event for American literature took place, Melville and Hawthorne met. There was a difference of fifteen years in age; Melville believed he was finishing his Moby-Dick, as we know by the letter he had written to his English publisher on June 27, and Hawthorne was enjoying the success of The Scarlet Letter. ${ }^{15}$ Each man was impressed by the other and each would portray the new friend's personality in future works.

At about that same time, Melville wrote "Hawthorne and his Mosses", a review of Mosses from an Old Manse, in which he poured out his feelings for Hawthorne. Melville, unlike Hawthorne, could not look at people and events in a detached way. As he said in a famous letter to Hawthorne, "I stand for the heart. To the dogs with the

13. Melville, Moby-Dick, p. 315.

14. See Robert K. Martin, Hero, Captain and Stranger.

15. Melville was being optimistic, in fact he would not finish Moby-Dick until 1851. 
head! I had rather be a fool with a heart, than Jupiter Olympus with his head". ${ }^{16}$ Melville was moved, it was his heart that was impregnating his writing of "Hawthorne and his Mosses". Was this commotion of Melville caused only by Hawthorne the artist or also by Hawthorne the man? There is so much intensity in his criticism that one might well believe Hawthorne was already a tangible image for Melville when he wrote "... already I feel that this Hawthorne has dropped germinous seeds into my soul". ${ }^{17}$ The article with this outburst was published on August 17 and 24, 1850, and it is reasonable therefore to assume that if Melville had not written the whole thing after meeting Hawthorne, at least he must have revised it.

What is the scope of Melville's evaluation of Mosses from an Old Manse? Is Melville referring to Hawthorne's literary influence on him? As an isolated incident it could be interpreted so, but when looking at the whole picture it becomes increasingly difficult not to see some strong personal attachment. We must here consider the degree and quality of the impression made by Hawthorne on the younger artist. There is enough evidence to assert that Melville was impressed, if not infatuated by Hawthorne, and let us not forget either that Hawthorne was often described as a physically beautiful man.

The personal letters that Melville wrote to Hawthorne while they were both living in the Berkshires are of the utmost importance. There is a difference of tone in comparison with other personal letters of Melville at that period. To express a communion of feelings, for instance, he writes to Richard Henry Dana Jr. that he [Melville] was "tied \& welded to you by a sort of Siamese link of affectionate sympathy". 18 To again express a community of feelings he writes to Hawthorne: "But I felt pantheistic then, your heart beat in my ribs and mine in yours, and both in God's". A little farther down in the same letter he adds: "Whence come you Hawthorne? By what right do you drink from my flagon of life? And when I put it to my lips-lo, they are yours and not mine". ${ }^{19}$ Of course we must place this language in the context of the mid-nineteenth century, but I would like to draw attention to the comparison between these two very different types of emotional language that Melville chose for Dana and for Hawthorne. When Hawthorne is the receiver, Melville's language becomes infinitely more suggestive and intimate. If these ambiguous images are simply the metaphorical expression of a mind feverish in the presence of a kindred soul, the least that can be said is that Melville was platonically in love with the author of "Mosses from an Old Manse".

Melville's mind was undoubtedly feverish at the time. He was also in very good spirits, especially when he was with the Hawthorne family. If all the descriptions we

16. Melville, The Letters of Herman Melville, p. 129.

17. Melville, "Hawthorne and His Mosses" Billy Budd and Other Prose Pieces, p. 139.

18. Melville, The Letters of Herman Melville, p. 106.

19. Melville, The Letters of Herman Melville. p. 142. 
have of Melville came from the Hawthornes' private writings, the traditional picture of Melville would be very different from the one we are accustomed to. It is not known that Melville ever was a favourite with children, but Hawthorne once wrote in The American Notebooks that his son Julian had said that "he loved Mr. Melville as well as me and as mamma and as Una".20 Sophia also thought he was "very agreeable and entertaining". ${ }^{21}$ Hawthorne himself said in a letter to Horatio Bridge, "I met Melville the other day, and like him so much that I have asked him to spend a few days with me... "22 These words uttered by an aloof personality such as Hawthorne's were a great compliment. How can we reconcile all these impressions with the generally held idea that Melville was a tormented human being? One explanation may be that it was Hawthorne's company that generated this geniality and animation. He was certainly excited enough to vividly dramatise his story telling and to dress up as a "Spanish caballero" in order to amuse his friend. ${ }^{23}$ Hawthorne, nevertheless, knew that there was much more in Meivilile than an entertaining personality. He had recognised genius and he would write about him in his journals from England in 1856: "He has a very high and noble nature and it is better worth immortality than most of us". ${ }^{24}$

Hawthorne wholly apprehended Melville's excitement and he reflected it through a character in his following novel The Blithedale Romance where Melville is clearly represented by the character of Hollingsworth, the passionate man who is so desperately seeking a friend of his own sex, the man who withholds his love from the two women who care about him to offer it to another man, Coverdale, to whom he murmurs: "There is not the man in this wide world, whom I can love as I could you. Do not forsake me!"'25 If Hawthorne pictured the situation faithfully one would be inclined to believe with Vernon Parrington that there is no tragedy like Herman Melville's in the entire history of American literature.

If Melville's desire for male friendship might have been partially provoked by his father's underappreciation and death, his peculiar view of women might have been caused by his mother's dominance. Melville's mother's influence on his writings was more complicated than his father's. He was brought up in a matriarchal household. His mother, Maria Gansevoort, was the only daughter of a well-to-do family from Albany and when she married Allan Melvill (a name she would later change to Melville) the couple lived with Maria's widowed mother for four years. Allan allowed his first son to be named Gansevoort Melvill and he and the rest of the children were all baptised into the Dutch Reformed Faith. Maria was the daughter of an army general and had

20. Nathaniel Hawthorne, The American Notebooks, p. 468.

21. Leon Howard, Herman Melville, p. 160.

22. Howard P. Vincent, Melville and Hawthorne in the Berkshires: A Symposium, p. 14.

23. Julian Hawthorne, Nathaniel Hawthorne and His Wife, p. 415.

24. Nathaniel Hawthorne, Passages From the English Note-Books, Vol. II. p. 156.

25. Nathaniel Hawthorne, The Blithdale Romance, p. 518. 
been brought up among men. She was therefore used to a rigid discipline to which she tried to convert her husband. She obviously judged, in view of Allan's failures, that the Melvills' way of life was inferior to that of the Gansevoorts which had for so long provided wealth and social status to her.

Unable to control her family by means of her scarce strength she tried and succeeded in subduing them using her weaknesses. One was her delicate health. She suffered periods of depression and was very often confined to her room. According to her brother Peter she was given to "unpleasant fainting fits". ${ }^{26}$ The entire family was probably afraid of doing anything that could have injured her health and tried hard to please her. When her husband died another means of control was added to Maria's list. She gained the right to be unhappy and her unhappiness gave her a stronger hold on the family. In spite of her love for the children, her nerves and her continuous complaints and self-pity must have created an environment for Herman and his siblings that was neither pleasant nor enriching. It is in just this atmosphere into which Herman was born and brought up.

Maria Melville's stress and nervousness are well documented and Herman was surely affected to some degree. It is relevant to remember at this point that psychologists researching on sexual behaviour have suggested in several studies that stress-prone mothers are more likely to have homosexual sons. For young Herman an affectation of this type seems possible according to this research.27

Melville was not only subjected to his mother's nerves; he also seems to have been subjected to her will during the greater part of his life. It is likely that his marriage had something to do with her. Maria's class consciousness and her anguish caused by the lack of money may have been two important factors in Herman's marriage to Elizabeth Shaw. Eleanor Melville Metcalf believes that in the matter of Herman's marriage "one cannot help feeling that Maria Melville had used a steering oar, that the ocean currents were supplemented by her activity".28

Whether Maria was the architect of the marriage is impossible to substantiate. Nevertheless there is a number of critics who consider the union strange and Newton Arvin, among them, finds it difficult to understand. He sees nothing in Elizabeth that might have attracted Melville in a romantic way and believes there is "a very large strain of the brotherly" in Melville's feelings for his wife. ${ }^{29}$ Nevertheless, there have been many other interpretations. Leon Howard saw it in a much more positive light, and in his biography of Melville he emphasised that Herman and Elizabeth were faithful to each other for over forty years. He also points out as a harbinger of future

26. Leyda, p. 19.

27. J. Michael Bailey, "A test of the Maternal Stress Theory of Human Male Homosexuality" Archives of Sexual Behavior, 20, June, 1991, pp. 277-293.

28. Eleanor Melville Metcalf, Herman Melville; Cycle and Epicycle, p. 42.

29. Newton Arvin, Herman Melville, p. 127. 
happiness that the groom found a four-leaf clover on the wedding day. ${ }^{30} \mathrm{It}$ is true that in the long run Melville's marriage proved to be beneficial to him in many ways, but it is just as true that it was also the source of intense dissatisfaction.

It can be documented that for a time the Shaws were trying to talk Elizabeth into leaving Herman. There is a letter from Elizabeth's brother, Samuel S. Shaw, to Henry Whitney Bellows, Minister of All Souls Unitarian Church in New York of which the Melvilles were members, which proves that there were serious marital difficulties and that Elizabeth had long been complaining about Herman's eccentricities. ${ }^{31}$

Herman's domestic difficulties with his mother and with his wife were reflected in his writings. Melville, no doubt because of his experiences at home, felt uncomfortable dealing with women characters perhaps because he also felt uncomfortable with them in real life. It is not easy to find a "normal" woman in his works. They are either dominant and emasculating as the wife in "I and My Chimney" and Mrs. Glendinning in Pierre, or completely idealised as Yillah in Mardi, or non-existent as in Billy Budd. In fact, it seems as if the only "normal" woman is the absent one. He had also difficulties picturing life in a happy marriage. Arvin points out that only five years after getting married he was indifferent enough to his wife's feelings to speak about "the disenchanting glasses of the matrimonial days and nights". We do not know if Elizabeth was affected by this opinion of marriage her husband had voiced in Pierre, but we know that when a negative view of domestic life was depicted in "I and $\mathrm{My}$ Chimney" she was offended enough to write in the margin of the manuscript: "all this about his wife applied to his mother".

How much of Melville's negative feelings towards women is owed to his mother? For some commentators she is the main source of his ambiguities. Many years after she had died his feelings for her were still very obscure. Arvin points out that Melville in his old age remarked to his niece, Mrs. Moorwood, that his mother "hated him". Arvin's interpretation of these words is that "Melville on one side of his nature hated his mother and that quite transparently he attributed his own sentiment to her". He also believes that "if he was capable of entertaining such an emotion it could only have been because he loved Maria Melville not with deficiency but with excessive love".32 As everything else in Melville's life, his feelings for Maria were contradictory, difficult to decipher, and extremely intense.

All this lack of fulfilment with women, together with the previously discussed circumstances, gave Melville his unique way of looking at the world. Losses in life are often a source of creativity. Inadequacy, loneliness, lack of beauty are highly influential experiences for the human spirit. When felt in the degree to which Melville

30. Howard, Herman Melville, p. 107.

31. Walter D. Kring and Jonathan S. Carey, "Two Discoveries Concerning Herman Melville" Proceedings of the Massachusetts Historical Society 87 (1975) 136-141.

32. Arvin, p. 128. 
seems to have felt them they may give way to alienation or to a need for expression. When it is an artist who is feeling them the result may be a work of art and of this we have a fine example in Melville's writings. His attempts to satisfy the vacuums in his life, his resulting literary characters, situations, and omissions all lead us to suspicions of latent homosexuality. Signs and evidences can be found and it only remains for us to say that whatever his orientation might truly have been, the aftermath has been one of the finest contributions to American literature.

\section{Works Cited}

ARVIN, N. Herman Merville. New York: Sloane, 1950.

BAILEY, J. M. "A test of the Maternal Stress Theory of Human Male Homosexuality" Archives of Sexual Behavior 20 (June, 1991).

HAWTHORNE, J. Nathaniel Hawthorne and His Wife. (2 Vols.) Boston: James R. Osgood and Company, 1885.

HAWTHORNE, N. The American Notebooks. ed. Claude M. Simpson. Columbus: Ohio State University Pres, 1972.

HAWTHORNE, N. The Blithdale Romance. New York: The Modern Library of America, 1937.

HAWTHORNE, N. Passages From the English Note-Books. Boston Houghton Mifflin and Company, 1870.

HOWARD, L. Herman Melville. Berkeley and Los Angeles: University of California Press, 1951.

KRING D. Walter and Jonathan S. Carey. "Two Discoveries Concerning Herman Melville" Proceedings of the Massachusetts Historical Society 87 (1975).

LEYDA, J. The Melville Log. (Vols 2). New York: Harcourt, Brace and Company, 1951.

MARTIN, R.K. Hero Captain and Stranger. Chapel Hill and London: The University of North Carolina, 1986.

MELVILLE, H. Billy Budd and Other Prose Pieces. ed. Raymond W. Weaver. New York: Russel and Russel Inc., 1963.

MELVILLE, H. Great Short Works of Herman Melville. ed. Warner Berthoff. New York: Harper and Row Publishers, 1969

MELVILLE, H. Journal of a Visit to Europe and the Levant. ed. Howard C. Horsford Princeton: Princeton University Press, 1955.

MELVILLE, H. The Letters of Herman Melville. ed. Merrel R. Davis and William H. Gilman. New Haven: Yale University Press, 1960.

MELVILLE, H. Journals. Chicago: Northwestern University Press, 1989.

MELVILLE, H. Moby-Dick. ed. Harrison Ford and Hershel Parker. New York and London: W. W. Norton and Company, 1967. 
MELVILLE, H. Redburn. Vol. 2 New York: Russel and Russel Inc., 1963.

MELVILLE, H. Typee. New York: The Library of America, 1892.

METCALF, E.M. Herman Melville: Cycle and Epicycle. Westport, CN: Grennwood Press Publishers, 1953.

MURRAY, H.A. Melville and Hawthorne in the Berkshires: A Symposion. Kent: Kent State University Press, 1968.

TOLCHING, N.L. Mourning, Gender and Creativity in the Art of Herman Melville.

New Haven and London: Yale University Press, 1988.

VINCENT, H. P. ED. Melville and Hawthorne in the Berkshires: A Symposium. Kent: Kent State University Press, 1968. 